\title{
Hypoxic Preconditioning Protects against Ischemic Brain Injury
}

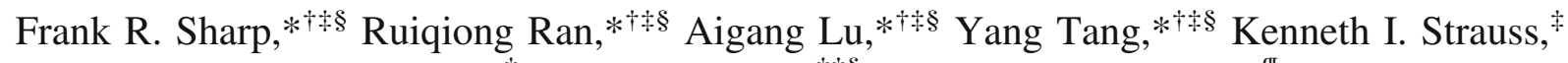 \\ Todd Glass, ${ }^{\dagger}$ Tim Ardizzone, ${ }^{*}{ }^{\dagger \S}$ and Myriam Bernaudin ${ }^{\mathbb{T l}}$ \\ *Departments of Neurology, ${ }^{\dagger}$ Pediatrics, ${ }^{\ddagger}$ Neurosurgery, ${ }^{\S}$ Neuroscience Program, University of Cincinnati, Cincinnati, Ohio \\ 45267; and ${ }^{\text {II } U M R ~} 6551$ Centre National de la Recherche Scientifique, ${ }^{\mathrm{II}}$ Université de Caen, IFR 47, Caen, France
}

\begin{abstract}
Summary: Animals exposed to brief periods of moderate hypoxia ( $8 \%$ to $10 \%$ oxygen for 3 hours) are protected against cerebral and cardiac ischemia between 1 and 2 days later. This hypoxia preconditioning requires new RNA and protein synthesis. The mechanism of this hypoxia-induced tolerance correlates with the induction of the hypoxia-inducible factor (HIF), a transcription factor heterodimeric complex composed of inducible HIF- $1 \alpha$ and constitutive HIF- $1 \beta$ proteins that bind to the hypoxia response elements in a number of HIF target genes. Our recent studies show that HIF- $1 \alpha$ correlates with hypoxia induced tolerance in neonatal rat brain. HIF target genes, also induced following hypoxia-induced tolerance, include vascular endothelial growth factor, erythropoietin, glucose transporters,
\end{abstract}

glycolytic enzymes, and many other genes. Some or all of these genes may contribute to hypoxia-induced protection against ischemia. HIF induction of the glycolytic enzymes accounts in part for the Pasteur effect in brain and other tissues. Hypoxiainduced tolerance is not likely to be equivalent to treatment with a single HIF target gene protein since other transcription factors including Egr-1 (NGFI-A) have been implicated in hypoxia regulation of gene expression. Understanding the mechanisms and genes involved in hypoxic tolerance may provide new therapeutic targets to treat ischemic injury and enhance recovery. Key Words: Hypoxia, preconditioning, hypoxia-inducible factor, HIF, VEGF, erythropoietin, EPO, ischemia, stroke, oxygen, stress proteins.

\section{INTRODUCTION}

\section{Definitions}

Hypoxia preconditioning refers to a period of hypoxia followed by a period of time, often between 1 and 2 days later, during which there is protection from an otherwise lethal insult. Hypoxia is defined as a decrease in tissue or ambient tissue oxygen concentration below normal. Ischemia is defined as a decrease in blood flow to tissue that prevents adequate delivery of oxygen and glucose and other nutrients. Stroke or infarction are defined as the death of most or all cellular elements in the tissue, i.e., in brain this is death of neurons, glia, and other cells, often including the vascular cells themselves.

\footnotetext{
Address correspondence and reprint requests to Frank R. Sharp, Departments of Neurology and Pediatrics, University of Cincinnati, Vontz Center for Molecular Studies Room 2327, 3125 Eden Avenue, Cincinnati, OH 45267-0536. E-mail: frank.sharp@uc.edu.

Supported by an American Heart Association Bugher 70006N Award, and National Institutes of Health grants NS38743, AG19561, NS43252, and NS28167 (to F. R. S.).
}

\section{Different types of preconditioning in different organs}

There are a number of types of preconditioning that are being studied in the brain, heart, retina, liver, kidney, and other organs. ${ }^{1-3}$ Some of these studies use ischemic preconditioning where blood flow is temporarily decreased before an ischemic insult that would ordinarily produce infarction. ${ }^{4-16}$ Hypoxia preconditioning has been described in the brain, heart, retina, and other tissues. ${ }^{10,14,15,17-35}$ Other types of preconditioning have been described in vivo and in vitro including hyperthermia, ${ }^{7,8,36}$ hypothermia, ${ }^{37,38}$ chemical preconditioning by blocking the Krebs cycle or respiratory chain, ${ }^{39}$ glutamate and seizures, ${ }^{5,29}$ linoleic acid, ${ }^{5}$ erythropoietin, ${ }^{40}$ tumor necrosis factor (TNF) ${ }^{41}$ ceramide, ${ }^{41,42}$ desferrioxamine and cobalt, ${ }^{43,44}$ isoflurane, ${ }^{45}$ thrombin, ${ }^{46,47}$ and others. ${ }^{3}$

\section{Why study preconditioning and its mechanisms?}

Gidday et al..$^{20,21}$ first showed that exposure of neonatal rat pups to hypoxia alone (8\% oxygen for 3 hours) protected these animals 1 day later from a stroke produced by combined hypoxia/ischemia using a carotid occlusion and exposure to $8 \%$ oxygen for 3 hours. ${ }^{31}$ In addition, exposure to hypoxia also protected adult ro- 
dents against stroke. ${ }^{22,48}$ Although the mechanisms of hypoxic preconditioning and ischemic preconditioning are still being elucidated, both of these types of preconditioning appear to require synthesis of new RNA and protein. ${ }^{4,9,10,18,20,33}$ Thus, studies designed to look at induction of RNA or protein should identify the molecules associated with the preconditioning. These results also suggest that down-regulation of RNA or protein synthesis is not likely to be the primary mechanism mediating either hypoxia or ischemic tolerance.

Though this review is directed mainly at hypoxia preconditioning, there has been a tendency to confuse hypoxia with ischemia pre-conditioning and even other types of conditioning. Some of the confusion over mechanisms of hypoxia-induced tolerance could be related to the degree of hypoxia. If animals are exposed to oxygen levels below about $8 \%$ to $9 \%$ they develop cardiac arrhythmias and systemic hypotension and ischemia that may induce genes related to the systemic ischemia and not due to the hypoxia itself. ${ }^{49,50}$ Therefore, in any hypoxia preconditioning paradigm it is essential to ensure that the cardiac rhythm is maintained along with blood pressure $^{20,22,48}$ to not to confuse ischemic and hypoxic preconditioning.

A number of mechanisms and molecules have been linked with various types of preconditioning. These include adenosine A1 receptors, ATP-sensitive potassium channels, nuclear factor $\kappa \mathrm{B}(\mathrm{NF} \kappa \mathrm{B})$, vascular endothelial growth factor (VEGF), erythropoietin (EPO), NOS, hypoxia-inducible factor (HIF), $N$-methyl-D-aspartate (NMDA) receptors, MnSOD, TNF, glycogen, lactate, and others. $5,6,10,13,17,21,23,24,29,32,35,41,43,51-54$ Unfortunately, this array of different molecules has not yielded a clear systematic approach to understanding mechanisms of preconditioning.

One method for making sense of the preconditioning paradigms is to examine the similarities between the genes induced by these different paradigms. We propose that a given stimulus is likely to produce characteristic changes in gene expression that has similarities in every organ, including the brain, and following various types of pre-conditioning. For example, following ischemia, hypoglycemia, hypoxia, and kainate-induced seizures there is a subset of genes induced by all of these conditions. ${ }^{55-57}$ Examples include certain sets of genes induced by low levels of glucose, called glucose-regulated proteins (GRPs) and endoplasmic-regulated proteins (ERPs). ${ }^{36,58-64}$ HIF-regulated proteins are specific gene products that are induced by hypoxia, also known as oxygen-regulated proteins (ORPs) or hypoxia-regulated proteins (HRPs). ${ }^{49,65-67}$ In addition, unique sets of genes are regulated by hemorrhage in the brain, which may relate to the presence of free heme and hemoglobin. ${ }^{36,55,56}$ We suggest that following transient exposure to each of the above types of insults, including ischemia, hypoglycemia, and seizures, glutamate, hemorrhage, and thrombin could precondition brain to resist subsequent injuries. A rational approach for searching for mechanisms of preconditioning would be to search for those molecules and pathways that are common to many or all of these injuries, or to concentrate on the mechanisms that might be most fundamental for cell survival from all of these injuries. ${ }^{56}$ This approach is supported by our recent findings that a number of genes are regulated in common in brain by ischemia, hypoglycemia, status epilepticus, and hemorrhage. ${ }^{56} \mathrm{We}$ propose that transcription factors, regulated in parallel by multiple injury modalities, would affect many common pathways, and thus would be the most promising candidates in the search for the molecules responsible for protection or repair.

\section{HYPOXIA PRECONDITIONING IN BRAIN AND OTHER ORGANS}

We have chosen to pursue the mechanisms of hypoxia preconditioning for several different reasons. First, hypoxia preconditioning has been shown to protect the brain and the heart against ischemia, as well as protect the brain from several types of injury including ischemia, seizures, and edema. ${ }^{10,14,18-25,27-32,35,49,54,66,68-76}$ Hypoxia protects many types of ischemia including focal and global ischemia in adult and neonatal brain with and without reperfusion. ${ }^{10,20,22,31,33,48}$ Hypoxia-induced tolerance in brain is not blocked by glutamate receptor antagonists, but is blocked by inhibitors of RNA and protein synthesis. ${ }^{10,19,20,33}$ This suggests that increased transcription and translation are necessary for hypoxiainduced tolerance or protection, and that studies designed to demonstrate increases of RNA or protein should be able to detect the molecules associated with this tolerance and protection. Finally, many of the molecules implicated in various other types of preconditioning are also induced by hypoxia or hypoxia-induced tolerance. $^{43,51,52,66,77,78}$

Many of the molecules induced by hypoxia are known to be protective, e.g., EPO, VEGF, and others. ${ }^{47}$ In addition, ischemia, thrombin, hemorrhage, and possibly hypoglycemia all induce HIF and HIF target genes. ${ }^{43,44,51,52,56,79}$ that have been implicated in hypoxia-induced tolerance, as described below. ${ }^{10,43}$

Finally, mild to moderate hypoxia ( $>8 \%$ oxygen) does not produce cell death in brain ${ }^{50,57}$ if hypoxia does not produce cardiac arrhythmias and hypotension. ${ }^{50}$ However, recent studies do show that hypoxia can damage both nuclear and mitochondrial DNA in brain cells and that this stimulates DNA repair. ${ }^{80-83}$ This hypoxia-induced DNA damage is obviously of great interest related to neural protection and degenerative neurological diseases. Whether this DNA repair response to hypoxia 
plays an important role in cellular protection afforded by hypoxia preconditioning is not known.

\section{HIF AND HYPOXIA PRECONDITIONING}

As noted, hypoxia preconditioning requires the synthesis of new RNA and new protein for protection against brain ischemia and is not dependent upon activation of glutamate receptors..$^{20}$ One potential candidate for this protection was heme oxygenase, a stress protein that protects against ischemia and is induced by hypoxia in some systems. ${ }^{63,84}$ However, hypoxia of the duration necessary to induce hypoxic tolerance does not induce heme oxygenase in brain. ${ }^{84}$

We next turned our attention to a transcription factor recently implicated in oxygen sensing and gene responses to hypoxia, HIF. HIF is composed of two proteins, HIF- $1 \alpha$ and HIF- $1 \beta$. HIF- $1 \alpha(120 \mathrm{kDa})$ and HIF-1 $\beta$ (91 to $94 \mathrm{kDa}$ ) are basic helix-loop-helix (bHLH) proteins of the PAS family (named for Per, ARNT, and Sim, the first members recognized). The bHLH domain, near the $\mathrm{N}$ terminus in both proteins, is essential for DNA binding. There are two transcriptional activation domains in HIF- $1 \alpha$ referred to as the N-terminal activation domain (NAD) and the C-terminal activation domain (CAD). Between these two domains is an oxygen-dependent degradation domain (ODD), which, when deleted, confers stability of the protein in the presence of oxygen. ${ }^{77,85,86}$

HIF- $1 \alpha$ can be substituted by recently described homologous proteins including HIF- $2 \alpha$ (also called EPAS1, HOP2, HLF), HIF-3 $\alpha$, and perhaps others. ${ }^{77}$ HIF- $1 \beta$, also called ARNT, is expressed constitutively in all cells, does not respond to changes of oxygen tension, but is essential for hypoxia-induced changes of transcription mediated by the HIF heterodimer. ${ }^{66}$ Knockout of either HIF- $1 \alpha$ or HIF- $2 \alpha$ is embryonic-lethal, showing that each has unique functions, and the absence of HIF- $1 \beta$ prevents HIF activation of gene transcription. ${ }^{65,66,77}$ These data suggest that although HIF- $1 \alpha /$ HIB- $1 \beta$ dimers and HIF- $\alpha /$ HIF- $1 \beta$ dimers bind the same DNA sequences, they either bind slightly different DNA sequences and therefore different target genes, or are differentially expressed in different tissues, resulting in non-overlapping functions. ${ }^{77}$

HIF- $1 \alpha$ protein is absent or nearly absent in most normoxic cells. With the onset of hypoxia, oxygen-sensing mechanisms immediately stabilize the HIF- $1 \alpha$ protein, which is continuously being synthesized from HIF- $1 \alpha$ mRNA. HIF- $1 \alpha$ protein dimerizes with HIF- $1 \beta$ protein, and along with other transcription factors (e.g., p300/CRB) bind to hypoxia response elements (HREs) in the regulatory regions of target gene's DNA. This transcriptional complex induces the transcription of HIF target genes including VEGF, EPO and others, as de-

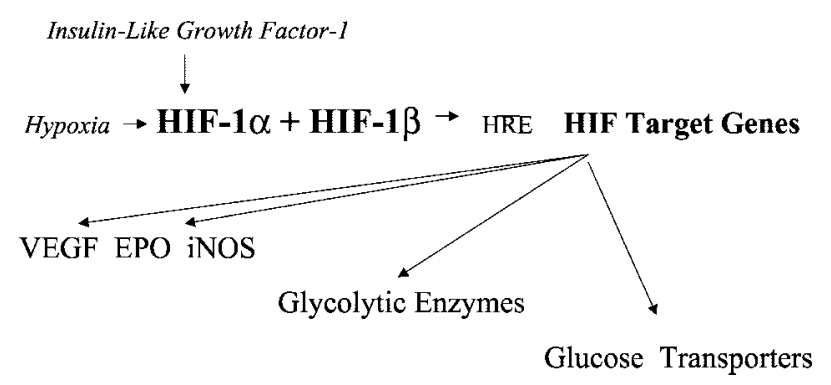

FIG. 1. Hypoxia and growth factor stabilization of HIF-1 $\alpha$ leads to binding to HIF-1 $\beta$ and binding to HREs in promoters of HIF target genes to activate transcription of HIF target genes.

scribed below. ${ }^{65,66,78,86-89}$ In addition, hypoxia activates HIF- $1 \alpha$ transcription, as described below, resulting in more HIF- $1 \alpha$ protein and HIF target gene induction. ${ }^{66}$

To have relevance to preconditioning in the brain, HIF should be induced in brain following ischemia and hypoxia. We found that focal cerebral ischemia (produced using the suture model in adult rats) induced mRNAs encoding HIF- $1 \alpha$, glucose transporter-1, lactate dehydrogenase, and several other glycolytic enzymes in the periinfarct penumbra. ${ }^{51}$ This was observed by 8 hours after the onset of ischemia and increased further at 19 and 24 hours. In areas of HIF-1 and HIF-1 target gene induction regional cerebral blood flow was moderately decreased at 1 and 24 hours after ischemia. Because hypoxia induces HIF-1 in other tissues, systemic hypoxia $\left(6 \% \mathrm{O}_{2}\right.$ for 4.5 hours) was also shown to increase HIF- $1 \alpha$ protein expression in the adult rat brain. ${ }^{51}$ It was proposed that decreased blood flow to the penumbra decreases the supply of oxygen and that this induces HIF- $1 \alpha$ mRNA, stabilizes HIF- $1 \alpha$ protein, which leads to induction of HIF-1 target genes. This was the first study to show induction of HIF-1 after focal ischemia in brain and suggest that durations of hypoxia sufficient to produce tolerance or hypoxia-induced conditioning also induced HIF-1 in brain.

\section{OXYGEN-SENSING SYSTEM}

In the past few years the mechanisms of oxygen sensing and oxygen induction of HIF and HIF target genes has been the subject of intense investigation and discovery. Though some of the mechanisms are still unclear, the following pathways are believed to mediate hypoxia sensing and HIF induction of HIF target genes.

\section{Hypoxia stabilizes HIF-1 $\alpha$ protein leading to induction of HIF target genes}

With a marked decrease of oxygen (hypoxia) the von Hippel-Lindau protein (pVHL) dissociates from the HIF- $1 \alpha$ protein. This results in decreased degradation of HIF- $1 \alpha$ protein via the ubiquitin-proteasome system and the immediate accumulation of HIF- $1 \alpha$ protein $^{85,90-101}$; 


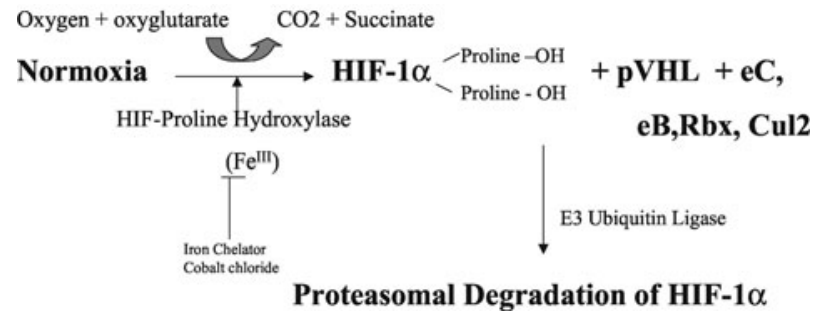

FIG. 2. Normoxia leads to activation of HIF proline hydroxylase, which hydroxylates two prolines on $\mathrm{HIF}-1 \alpha$ (prolines 402 and 564) that leads to binding of $\mathrm{pVHL}$ and elongin-C,-B, Rbx, and Cul2 and degradation of HIF- $1 \alpha$ in the proteasome.

the HIF- $1 \alpha$ protein then dimerizes with HIF-1 $\beta$ protein. This complex, including transcription factor $\mathrm{p} 300 / \mathrm{CRB}$, binds at HREs on HIF target genes to induce transcription of those genes (see FIG. 1). ${ }^{65,88,89,102-106}$ In addition, hypoxia induces the transcription of HIF $1 \alpha$ mRNA that increases HIF- $1 \alpha$ protein in the presence of continued hypoxia that also promotes transcription of HIF target genes. ${ }^{51,52,107}$

Upon establishing normoxic conditions, HIF $1 \alpha$ is rapidly degraded via the following recently described pathway. In the presence of dioxygen, iron, and oxoglutarate, one or several HIF protein hydroxylases (PH) (also called oxoglutarate dehydrogenases) are activated and proceed to hydroxylate proline residue 564 and one other proline residue on the HIF- $1 \alpha$ protein. ${ }^{85,92,96,108-115}$ Hydroxylation of these proline residues changes the HIF protein conformation, which allows it to be recognized by pVHL. Once pVHL binds diproline-hyroxylated HIF- $1 \alpha$, other factors bind to the complex including elongin $\mathrm{C}$, elongin $\mathrm{B}, \mathrm{Rbx} 1$, and Cul-2 (a member of the Cullin family). ${ }^{77,85,86,99,108}$ This complex acts as an E3 ubiquitin ligase for HIF- $1 \alpha$ polyubiquitination by targeting the ODD and degradation of HIF-1 $\alpha$ via the proteasome (FIG. 2). Mutations in wild-type pVHL lead to von Hippel-Lindau disease with failure to degrade HIF-1 $\alpha$, overexpression of various HIF-1 target genes including VEGF, and formation of various types of vascular tumors. ${ }^{77,86,98,99}$ Therefore, the oxygen sensor appears to be the protein hydroxylase that requires dioxygen and oxyglutarate as co-factors to hydroxylate at least two proline residues on the hypoxic HIF- $1 \alpha$ protein. ${ }^{85,92}$ These protein hydroxylases contain an iron that can be bound by chelators like desferrioxamine and displaced by heavy metal ions like cobalt, and account for HIF induction by these compounds. ${ }^{77,85,96}$ Of interest is the finding that $\mathrm{p} 53$ can bind HIF- $1 \alpha$ protein and mediate its degradation via MDM2 (another E3 ubiquitin ligase) in the proteasome independent of oxygen. ${ }^{77}$

\section{Hypoxia leads to increased transcriptional activity of HIF-1 $\alpha$}

In the presence of oxygen, an asparagine protein hydroxylase hydroxylates an asparagine on HIF- $1 \alpha$ protein that prevents the binding of p300 to HIF- $1 \alpha$ and prevents

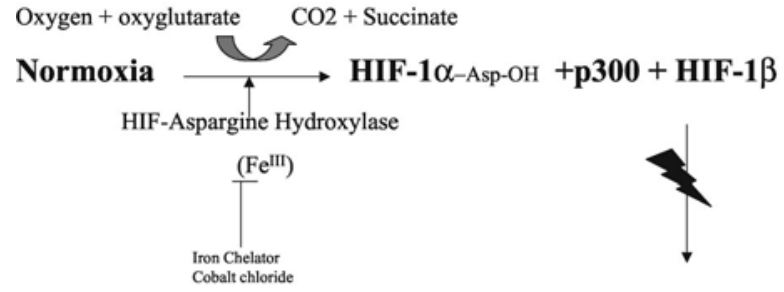

HIF Target Genes

FIG. 3. Normoxia leads to activation of HIF asparagine hydroxylase, which hydroxylates asparagine 803 on HIF- $1 \alpha$ that prevents binding of p300 to the HIF- $1 \alpha$ and HIF-1 $\beta$ complex and impairs activation of HIF target genes.

the transcriptional activation of HIF target genes. ${ }^{110,111}$ Therefore, during hypoxia the asparagine hydroxylase is inactivated, leading to active HIF- $1 \alpha$ protein, which dimerizes with HIF-1b that binds p300/CBP and activates HIF target genes (see FIG. 3). ${ }^{77}$

In addition, hypoxia leads to increased transcription of HIF- $1 \alpha$ mRNA and increased HIF- $1 \alpha$ protein in brain and in other organs. ${ }^{43,51,52,77}$ The mechanisms controlling the transcription of HIF- $1 \alpha$ mRNA and the translation of HIF- $1 \alpha$ mRNA into protein are still being defined. Heregulin and insulin-like growth factor 1 (IGF-1) induced phosphorylation of the translational regulatory proteins 4EBP-1, p70 S6 kinase, and EIF4E. ${ }^{77}$ These proteins are substrates for the phosphatidyl 3-kinase (PI3K)/AKT-FRAP/mTOR (FKBP12-rapamycin-associated protein/mammalian target of rapamycin cascade). This cascade can be activated by a variety of factors, including growth factors and cytokines including EGF, heregulin, insulin, IGF-like growth factors, interleukin (IL) $-1 \beta$ and others to induce HIF- $1 \alpha$ accumulation and target gene expression. ${ }^{66,77,116,117}$ IGF in brain also plays a role in increasing HIF target gene transcription. ${ }^{118} \mathrm{~A}$ number of studies show that inhibitors targeting PI3K or FRAP/mTOR prevent growth factor- and cytokine-induced HIF- $1 \alpha$ accumulation. ${ }^{77}$ PTEN overexpression, which dephosphorylates PI3K targets, also decreases HIF- $1 \alpha$ expression in glial cell lines. ${ }^{119}$ This pathway may explain how thrombin induces HIF in brain ${ }^{47}$ and possibly the various interactions of $\mathrm{NF} \kappa \mathrm{B}$, early growth response factor-1 (Egr1), Etx, glucose, and HIF. ${ }^{28,60,74,120-122}$ In addition, many HIF target genes likely have promoter elements that respond to many factors in addition to HIF, including Egr-1, NF $\kappa \mathrm{B}$, glucose-regulated proteins, Ets/Elk-1, PKC, Raf, mitogen-activated protein kinase (MAPK), extracellular signal-regulated kinase (ERK), and others. ${ }^{28,47,60,74,118,120-127}$

\section{HIF TARGET GENES}

HIF target genes include those related to vasomotor control (NOS2), angiogenesis (VEGF, FLT-1), blood 
and iron metabolism (EPO, transferrin, transferrin receptor, ceruloplasmin), cell proliferation [IGF-1, IGFBP-1, -3 , transforming growth factor (TGF) $\beta$ ], and energy metabolism (glucose transporter-1, -2 , and -3 , phosphoenolpyruvate carboxylase, lactate dehydrogenase $\mathrm{A}$, aldolase, phosphoglucokinase-1, -L and -C, pyruvate kinase, enolase, and many others, including prolyl 4-hydroxylase and adenomedullin). ${ }^{65,88,89,104,105}$ Many additional genes are likely HIF targets. ${ }^{52,104}$ Tyrosine hydroxylase is an important HIF target gene with several HREs in its promoter that may well use EPAS1 rather than HIF- $1 \alpha .{ }^{128,129}$ Plasminogen activator inhibitor-1, DEC1, a basic helix-loophelix transcription factor that is induced by hypoxia in glioma cells, the endothelin-1 gene and others appear to have functional HREs and respond to hypoxia. ${ }^{130-134}$

\section{HYPOXIA-INDUCED TOLERANCE BY PHARMACOLOGICAL INDUCTION OF HIF}

Hypoxic preconditioning is hypothesized to be due, at least in part, to hypoxic induction of HIF-1. This postulate was supported by the finding that a 3-hour exposure to $8 \%$ oxygen induced HIF- $1 \alpha$ but not HIF- $2 \alpha$ in neonatal rat brain. ${ }^{43,51,52}$ To further support the concept that hypoxic induction of HIF-1 confers tolerance to subsequent injury, animals pretreated with cobalt or desferrioxamine (compounds known to induce HIF-1, by binding to the iron in the oxygen sensor proteins ${ }^{65,78,85,87}$ ) are protected against ischemic injury in the neonatal and in the adult rodent brain. HIF- $1 \alpha$ and HIF- $1 \beta$ protein levels increase after intraperitoneal injection of cobalt chloride $(60 \mathrm{mg} / \mathrm{kg})$ and moderately increase after intraperitoneal injection of desferrioxamine $(200 \mathrm{mg} / \mathrm{kg}) 1$ to 3 hours after the injections. Preconditioning with cobalt chloride or desferrioxamine 24 hours before hypoxia-ischemia affords $75 \%$ and $56 \%$ brain protection, respectively, compared with that in vehicle-injected littermate controls. Thus, pharmacological induction of HIF-1 as well as hypoxic induction of HIF-1 appears to contribute to brain preconditioning.

It is interesting to note that the discovery of the protein hydroxylase oxygen sensor protein has made it possible to design small molecule mimics that bind the protein and also induce HIF. ${ }^{96}$ Such molecules might be used clinically. In addition, compounds already used clinically, including desferrioxamine and isoflurane, may also induce HIF and protect the brain and all other organs in the body against ischemia. ${ }^{1,44,45}$

\section{GENES INDUCED BY HYPOXIA PRECONDITIONING IN BRAIN}

\section{VEGF and EPO}

Several HIF target genes have already been directly implicated in protecting the brain and other organs against ischemia. These include VEGF and EPO. ${ }^{1,135-148}$ In addition, a recent human study suggests that early administration of EPO following stroke improves outcome in the patient population. ${ }^{143}$ Although the mechanisms of both molecules in protecting brain are likely to be complex, several different pathways have been studied. It has been suggested that EPO acts at EPO receptors to activate Jak2, which initiates phosphorylation of IKB to activate $\mathrm{NF} \kappa \mathrm{B}$ and induce $\mathrm{NF} \kappa \mathrm{B}$ neuroprotective genes. ${ }^{40}$ Jak2 also activates PI3K to phosphorylate Akt, which leads to phosphorylation and deactivation of the pro-apoptotic gene BAD ${ }^{79}$ VEGF not only promotes angiogenesis, but may also promote cell survival by acting at VEGF receptors that then lead to phosphorylation and activation of Akt that leads to cellular changes that promote cell survival. $^{33}$

Hypoxia preconditioning not only induces VEGF and EPO but also many other genes. Exposure of neonatal rats to 3 hours of $8 \%$ oxygen induces dozens of genes in brain including HIF- $1 \alpha{ }^{52}$ A related hypoxia transcription factor, HIF- $2 \alpha$, is not induced by hypoxia preconditioning in brain. Other genes that are induced by the hypoxia preconditioning include GLUT-1, adrenomedullin, propyl 4-hydroxylase, metallothionein-1, MKP-1, CELF, 12-lipoxygenase, tissue-type plasminogen activator (tPA), CAR-1, and a number of unidentified expressed sequence tags. ${ }^{52}$ The role of most of these molecules in mediating protection is unknown, though GLUT-1 has been shown to protect cells against ischemia and other types of injury. ${ }^{149-151}$

Other molecules might also have critical roles in hypoxia-induced tolerance. For example, at least one study showed that blocking the lactate transporter prevented hypoxia preconditioning in vitro. ${ }^{29}$ This intriguing result was interpreted to mean that hypoxia led to up-regulation of lactate transporters on astrocytes and neurons and that the shuttle of lactate from astrocytes to neurons was enhanced by hypoxia preconditioning, which improved cell survival, whereas blocking the lactate transporter prevented this cell survival mechanism. If this were the primary mechanism by which hypoxia preconditioning occurred, then approaches for selectively up-regulating glial and neuronal lactate transporters might be worth pursuing.

It is important to point out that the induction of HIF or the induction of a given HIF target gene/protein cannot be thought of as equivalent, because the factors that regulate HIF expression are different from the factors that regulate expression of any given HIF target gene. For example, hypoxia, along with at least selected cytokines and perhaps selected growth factors, induce HIF- $1 \alpha$ mRNA and/or stabilize HIF- $1 \alpha$ protein and stimulate HIF transcriptional activation. However, different factors regulate induction of the HIF target gene, VEGF. Not only are there HIF HREs in the VEGF promoter, but 
there also appear to be Egr-1, Sp1, Smad 3, Ap1, TGF, estrogen, and many other promoter sites that mediate VEGF induction by a wide variety of molecules including EGF, HGF, TGF, interferon, IL-1, IL-6, TNF, Egr-1, estrogen, calcium, STAT3, p44/p42 MAPK, IGF, Akt/ PI3K, mTOR, p53, and many others. ${ }^{33,87,152,153}$ The complex interaction of various factors on various promoter elements of VEGF and probably many other HIF target genes is highlighted by the finding that animals with a deletion of the HRE in the VEGF promoter have selective degeneration of motor neurons in the nervous system. ${ }^{153}$ The relationship of this finding to sporadic amyotrophic lateral sclerosis is unclear, but suggests possible roles of hypoxia and factors like VEGF.

\section{Complex role of HIF and other transcription factors regulated by hypoxia}

HIF and regulation of HIF target genes has recently been shown to be important in the life and death of a variety of different cells. As discussed above, cobalt or desferrioxamine induction of HIF appears to protect the brain against stroke. ${ }^{43,154}$ HIF has also been shown to be essential for the survival of certain cells/tissues in the body; for example, HIF- $1 \alpha$ is essential for chondrocyte growth arrest and survival. ${ }^{155}$ Cells that lack HIF-1 in the interior of the growth plate in bone die, and though HIF-induced VEGF is impaired, VEGF appears to be induced following hypoxia via a HIF-independent mechanism that can result in ectopic angiogenesis. ${ }^{155}$ Other hypoxia transcription factors that would induce VEGF include NF $\kappa$ B, Egr-1, NGFI-A, metal transcription factors and possibly CREB. ${ }^{124,156-161}$ The role of these other hypoxia-responsive transcription factors in hypoxia-induced tolerance is still unknown. Though HIF is clearly important, the relative roles of $\mathrm{NF} \kappa \mathrm{B}$, Egr- $1,{ }^{124}$ metal-responsive promoter element-binding transcription factor $(\mathrm{MTF})^{1}$, and CREB is still unclear. For example, tissue factor, VEGF, IL-1, PAI, TGF, 5-lipoxygenase, and other genes are regulated in part by hypoxia through Egr-1. 124,125,127,162-164

In addition, HIF- $1 \alpha$ is essential for myeloid cell-mediated inflammation. ${ }^{165}$ Activation of HIF- $1 \alpha$ is essential for myeloid cell infiltration and activation in vivo through a mechanism independent of VEGF. Loss of pVHL and up-regulation of HIF leads to a large increase in inflammatory responses. It appears that white blood cells obtain most of their ATP via glycolysis, and the absence of HIF-inducible glycolytic enzymes impairs the Pasteur effect in white blood cells. This impairs their function, including aggregation, motility, invasiveness, and bacterial killing. ${ }^{165}$

Though a number of studies suggest that HIF and HIF target gene induction appear to be protective, ${ }^{40,43,154}$ this is not always the case. HIF-1 induction mediates the stabilization and up-regulation of p53 and p53-mediated hypoxia-induced apoptosis in some types of cells in part by down-regulation of anti-apoptotic genes like Bcl-2 and up-regulation of pro-apoptotic genes. ${ }^{140,166-169}$

\section{Unanswered questions}

The above discussion addresses the general question of how gene discovery can be used in the search for molecules and pathways that might be drug targets for neuroprotection for stroke and other types of injury. Is it better to target a transcription factor like HIF that likely has many modes of action? Or is it better to target a given downstream gene like EPO that is likely to have fewer modes of action but also might have fewer side effects? Will targeting individual effectors provide just as much protection as hypoxia preconditioning itself? Are some of the molecules induced by hypoxia preconditioning actually harmful during ischemia, like tPA $?^{170-173}$ Does hypoxic preconditioning protect against all types of neural injuries-ischemia, hypoglycemia, trauma, hemorrhage, neurotoxins, status epilepticus-and degenerative neuronal cell death? The answers to these questions will hopefully provide new tools and new insights for developing treatments for the ischemic brain or preventing subsequent injury should ischemia occur.

\section{REFERENCES}

1. Hawaleshka A, Jacobsohn E. Ischaemic preconditioning: mechanisms and potential clinical applications. Can J Anaesth 45:670682, 1998.

2. Zhu Y, Ohlemiller KK, McMahan BK, Gidday JM. Mouse models of retinal ischemic tolerance. Invest Ophthalmol Vis Sci 43: 1903-1911, 2002.

3. Zimmermann C, Ginis I, Furuya K, Klimanis D, Ruetzler C, Spatz M, Hallenbeck JM. Lipopolysaccharide-induced ischemic tolerance is associated with increased levels of ceramide in brain and in plasma. Brain Res 895:59-65, 2001.

4. Barone FC, White RF, Spera PA, Ellison J, Currie RW, Wang X, Feuerstein GZ. Ischemic preconditioning and brain tolerance: temporal histological and functional outcomes, protein synthesis requirement, and interleukin-1 receptor antagonist and early gene expression. Stroke 29:1937-1950, 1998.

5. Blondeau N, Widmann C, Lazdunski M, Heurteaux C. Activation of the nuclear factor- $\kappa \mathrm{B}$ is a key event in brain tolerance. $\mathrm{J} \mathrm{Neu-}$ rosci 21:4668-4677, 2001.

6. Bond A, Lodge D, Hicks CA, Ward MA, O'Neill MJ. NMDA receptor antagonism, but not AMPA receptor antagonism attenuates induced ischaemic tolerance in the gerbil hippocampus. Eur J Pharmacol 380:91-99, 1999.

7. Chen J, Graham SH, Zhu RL, Simon RP. Stress proteins and tolerance to focal cerebral ischemia. J Cereb Blood Flow Metab 16:566-577, 1996.

8. Chen J, Simon R. Ischemic tolerance in the brain. Neurology 48:306-311, 1997.

9. Currie RW, Ellison JA, White RF, Feuerstein GZ, Wang X, Barone FC. Benign focal ischemic preconditioning induces neuronal Hsp70 and prolonged astrogliosis with expression of Hsp27. Brain Res 863:169-181, 2000.

10. Gage AT, Stanton PK. Hypoxia triggers neuroprotective alterations in hippocampal gene expression via a heme-containing sensor. Brain Res 719:172-178, 1996.

11. Kirino T. Ischemic tolerance. J Cereb Blood Flow Metab 22: 1283-1296, 2002.

12. Kitagawa K, Matsumoto M, Kuwabara K, Tagaya M, Ohtsuki T, Hata $\mathrm{R}$ et al. 'Ischemic tolerance' phenomenon detected in various brain regions. Brain Res 561:203-211, 1991. 
13. Munoz A, Nakazaki M, Goodman JC, Barrios R, Onetti CG, Bryan J, Aguilar-Bryan L. Ischemic preconditioning in the hippocampus of a knockout mouse lacking SUR1-based K(ATP) channels. Stroke 34:164-170, 2003.

14. Neckar J, Papousek F, Novakova O, Ost'adal B, Kolar F. Cardioprotective effects of chronic hypoxia and ischaemic preconditioning are not additive. Basic Res Cardiol 97:161-167, 2002.

15. Tajima M, Katayose D, Bessho M, Isoyama S. Acute ischaemic preconditioning and chronic hypoxia independently increase myocardial tolerance to ischaemia. Cardiovasc Res 28:312-319, 1994.

16. Tanaka H, Calderone A, Jover T, Grooms SY, Yokota H, Zukin RS, Bennett MV. Ischemic preconditioning acts upstream of GluR2 down-regulation to afford neuroprotection in the hippocampal CA1. Proc Natl Acad Sci USA 99:2362-2367, 2002.

17. Brucklacher RM, Vannucci RC, Vannucci SJ. Hypoxic preconditioning increases brain glycogen and delays energy depletion from hypoxia-ischemia in the immature rat. Dev Neurosci 24: 411-417, 2002.

18. Emerson MR, Nelson SR, Samson FE, Pazdernik TL. A global hypoxia preconditioning model: neuroprotection against seizureinduced specific gravity changes (edema) and brain damage in rats. Brain Res Brain Res Protoc 4:360-366, 1999.

19. Emerson MR, Nelson SR, Samson FE, Pazdernik TL. Hypoxia preconditioning attenuates brain edema associated with kainic acid-induced status epilepticus in rats. Brain Res 825:189-193, 1999.

20. Gidday JM, Fitzgibbons JC, Shah AR, Park TS. Neuroprotection from ischemic brain injury by hypoxic preconditioning in the neonatal rat. Neurosci Lett 168:221-224, 1994.

21. Gidday JM, Shah AR, Maceren RG, Wang Q, Pelligrino DA, Holtzman DM, Park TS. Nitric oxide mediates cerebral ischemic tolerance in a neonatal rat model of hypoxic preconditioning. J Cereb Blood Flow Metab 19:331-340, 1999.

22. Miller BA, Perez RS, Shah AR, Gonzales ER, Park TS, Gidday JM. Cerebral protection by hypoxic preconditioning in a murine model of focal ischemia-reperfusion. Neuroreport 12:1663-1669, 2001.

23. Moolman JA, Genade S, Winterbach R, Lochner A. Preconditioning with hypoxia versus global ischemia in the isolated rat heart: effect on function and metabolism. Cardioscience 5:73-80, 1994.

24. Perez-Pinzon MA, Mumford PL, Rosenthal M, Sick TJ. Anoxic preconditioning in hippocampal slices: role of adenosine. Neuroscience 75:687-694, 1996.

25. Rauca C, Zerbe R, Jantze H, Krug M. The importance of free hydroxyl radicals to hypoxia preconditioning. Brain Res 868: 147-149, 2000.

26. Rubaj A, Gustaw K, Zgodzinski W, Kleinrok Z, SiekluckaDziuba M. The role of opioid receptors in hypoxic preconditioning against seizures in brain. Pharmacol Biochem Behav 67:65$70,2000$.

27. Samoilov MO, Lazarevich EV, Semenov DG, Mokrushin AA, Tyul'kova EI, Romanovskii DY, Milyakova EA, Dudkin KN. The adaptive effects of hypoxic preconditioning of brain neurons. Neurosci Behav Physiol 33:1-11, 2003.

28. Sasaki H, Ray PS, Zhu L, Otani H, Asahara T, Maulik N. Hypoxia/reoxygenation promotes myocardial angiogenesis via an NF $\kappa \mathrm{B}$-dependent mechanism in a rat model of chronic myocardial infarction. J Mol Cell Cardiol 33:283-294, 2001.

29. Schurr A, Payne RS, Tseng MT, Gozal E, Gozal D. Excitotoxic preconditioning elicited by both glutamate and hypoxia and abolished by lactate transport inhibition in rat hippocampal slices. Neurosci Lett 307:151-154, 2001.

30. Shizukuda Y, Iwamoto T, Mallet RT, Downey HF. Hypoxic preconditioning attenuates stunning caused by repeated coronary artery occlusions in dog heart. Cardiovasc Res 27:559-564, 1993.

31. Vannucci RC, Towfighi J, Vannucci SJ. Hypoxic preconditioning and hypoxic-ischemic brain damage in the immature rat: pathologic and metabolic correlates. J Neurochem 71:1215-1220, 1998.

32. Wen HC, Lee CC, Lee WC, Huang KS, Lin MT. Chronic hypoxia preconditioning increases survival in rats suffering from heatstroke. Clin Exp Pharmacol Physiol 29:435-440, 2002.

33. Wick A, Wick W, Waltenberger J, Weller M, Dichgans J, Schulz JB. Neuroprotection by hypoxic preconditioning requires sequential activation of vascular endothelial growth factor receptor and Akt. J Neurosci 22:6401-6407, 2002.

34. Wu C, Zhan RZ, Qi S, Fujihara H, Taga K, Shimoji K. A forebrain ischemic preconditioning model established in C57Black/Crj6 mice. J Neurosci Methods 107:101-106, 2001.

35. Zhang WL, Lu GW. Changes of adenosine and its A(1) receptor in hypoxic preconditioning. Biol Signals Recept 8:275-280, 1999.

36. Sharp FR, Massa SM, Swanson RA. Heat-shock protein protection. Trends Neurosci 22:97-99, 1999.

37. Nishio S, Chen ZF, Yunoki M, Toyoda T, Anzivino M, Lee KS Hypothermia-induced ischemic tolerance. Ann N Y Acad Sci 890: 26-41, 1999.

38. Nishio S, Yunoki M, Chen ZF, Anzivino MJ, Lee KS. Ischemic tolerance in the rat neocortex following hypothermic preconditioning. J Neurosurg 93:845-851, 2000.

39. Riepe MW, Ludolph AC. Chemical preconditioning: a cytoprotective strategy. Mol Cell Biochem 174:249-254, 1997.

40. Digicaylioglu M, Lipton SA. Erythropoietin-mediated neuroprotection involves cross-talk between Jak2 and NF- $\kappa \mathrm{B}$ signalling cascades. Nature 412:641-647, 2001.

41. Ginis I, Jaiswal R, Klimanis D, Liu J, Greenspon J, Hallenbeck JM. TNF- $\alpha$-induced tolerance to ischemic injury involves differential control of NF- $\kappa \mathrm{B}$ transactivation: the role of NF- $\kappa \mathrm{B}$ association with p300 adaptor. J Cereb Blood Flow Metab 22:142$152,2002$.

42. Furuya K, Ginis I, Takeda H, Chen Y, Hallenbeck JM. Cell permeable exogenous ceramide reduces infarct size in spontaneously hypertensive rats supporting in vitro studies that have implicated ceramide in induction of tolerance to ischemia. $J$ Cereb Blood Flow Metab 21:226-232, 2001.

43. Bergeron M, Gidday JM, Yu AY, Semenza GL, Ferriero DM, Sharp FR. Role of hypoxia-inducible factor-1 in hypoxia-induced ischemic tolerance in neonatal rat brain. Ann Neurol 48:285-296, 2000.

44. Prass K, Ruscher K, Karsch M, Isaev N, Megow D, Priller J, Scharff A, Dirnagl U, Meisel A. Desferrioxamine induces delayed tolerance against cerebral ischemia in vivo and in vitro. J Cereb Blood Flow Metab 22:520-525, 2002.

45. Kapinya KJ, Prass K, Dirnagl U. Isoflurane-induced prolonged protection against cerebral ischemia in mice: a redox sensitive mechanism? Neuroreport 13:1431-1435, 2002.

46. Striggow F, Riek M, Breder J, Henrich-Noack P, Reymann KG, Reiser G. The protease thrombin is an endogenous mediator of hippocampal neuroprotection against ischemia at low concentrations but causes degeneration at high concentrations. Proc Natl Acad Sci USA 97:2264-2269, 2000.

47. Xi G, Reiser G, Keep RF. The role of thrombin and thrombin receptors in ischemic, hemorrhagic and traumatic brain injury: deleterious or protective? J Neurochem 84:3-9, 2003.

48. Bernaudin M, Nedelec AS, Divoux D, MacKenzie ET, Petit E, Schumann-Bard P. Normobaric hypoxia induces tolerance to focal permanent cerebral ischemia in association with an increased expression of hypoxia-inducible factor- 1 and its target genes, erythropoietin and VEGF, in the adult mouse brain. $J$ Cereb Blood Flow Metab 22:393-403, 2002.

49. Sharp FR, Bergeron M, Bernaudin M. Hypoxia-inducible factor in brain. Adv Exp Med Biol 502:273-291, 2001.

50. Simon RP. Hypoxia versus ischemia. Neurology 52:7-8, 1999.

51. Bergeron M, Yu AY, Solway KE, Semenza GL, Sharp FR. Induction of hypoxia-inducible factor-1 (HIF-1) and its target genes following focal ischaemia in rat brain. Eur $J$ Neurosci 11:4159 4170, 1999.

52. Bernaudin M, Tang Y, Reilly M, Petit E, Sharp FR. Brain genomic response following hypoxia and re-oxygenation in the neonatal rat. Identification of genes that might contribute to hypoxia-induced ischemic tolerance. J Biol Chem 277:3972839738, 2002.

53. Heurteaux C, Lauritzen I, Widmann C, Lazdunski M. Essential role of adenosine, adenosine A1 receptors, and ATP-sensitive $\mathrm{K}+$ 
channels in cerebral ischemic preconditioning. Proc Natl Acad Sci USA 92:4666-4670, 1995.

54. Lasley RD, Anderson GM, Mentzer RM Jr. Ischaemic and hypoxic preconditioning enhance postischaemic recovery of function in the rat heart. Cardiovasc Res 27:565-570, 1993.

55. Tang Y, Lu A, Aronow BJ, Sharp FR. Blood genomic responses differ after stroke, seizures, hypoglycemia, and hypoxia: blood genomic fingerprints of disease. Ann Neurol 50:699-707, 2001.

56. Tang Y, Lu A, Aronow BJ, Wagner KR, Sharp FR. Genomic responses of the brain to ischemic stroke, intracerebral haemorrhage, kainate seizures, hypoglycemia, and hypoxia. Eur J Neurosci 15:1937-1952, 2002.

57. Tang Y, Nee AC, Lu A, Ran R, Sharp FR. Blood genomic expression profile for neuronal injury. J Cereb Blood Flow Metab 23:310-319, 2003.

58. Massa SM, Longo FM, Zuo J, Wang S, Chen J, Sharp FR. Cloning of rat grp75, an hsp70-family member, and its expression in normal and ischemic brain. J Neurosci Res 40:807-819, 1995.

59. Kietzmann T, Krones-Herzig A, Jungermann K. Signaling crosstalk between hypoxia and glucose via hypoxia-inducible factor 1 and glucose response elements. Biochem Pharmacol 64:903-911, 2002.

60. Krones A, Jungermann K, Kietzmann T. Cross-talk between the signals hypoxia and glucose at the glucose response element of the L-type pyruvate kinase gene. Endocrinology 142:2707-2718, 2001.

61. Massa SM, Swanson RA, Sharp FR. The stress gene response in brain. Cerebrovasc Brain Metab Rev 8:95-158, 1996.

62. Poulaki V, Qin W, Joussen AM, Hurlbut P, Wiegand SJ, Rudge J, Yancopoulos GD, Adamis AP. Acute intensive insulin therapy exacerbates diabetic blood-retinal barrier breakdown via hypoxiainducible factor-1 $\alpha$ and VEGF. J Clin Invest 109:805-815, 2002.

63. Sharp FR. Stress genes protect brain. Ann Neurol 44:581-583, 1998.

64. Sharp FR, Lu A, Tang Y, Millhorn DE. Multiple molecular penumbras after focal cerebral ischemia. J Cereb Blood Flow Metab 20:1011-1032, 2000.

65. Ratcliffe PJ, O’Rourke JF, Maxwell PH, Pugh CW. Oxygen sensing, hypoxia-inducible factor-1 and the regulation of mammalian gene expression. J Exp Biol 201:1153-1162, 1998.

66. Semenza GL. Hypoxia-inducible factor 1: oxygen homeostasis and disease pathophysiology. Trends Mol Med 7:345-350, 2001.

67. Sharp FR, Bernaudin M, Bartels M, Wagner KR. Glial expression of heat shock proteins (HSPs) and oxygen-regulated proteins (ORPs). Prog Brain Res 132:427-440, 2001.

68. Emerson MR, Samson FE, Pazdernik TL. Effects of hypoxia preconditioning on expression of metallothionein-1, 2 and heme oxygenase-1 before and after kainic acid-induced seizures. Cell Mol Biol (Noisy-le-grand) 46:619-626, 2000.

69. Lu GW, Liu HY. Downregulation of nitric oxide in the brain of mice during their hypoxic preconditioning. J Appl Physiol 91: 1193-1198, 2001.

70. Marber MS, Yellon DM. Hypoxic preconditioning of ischaemic myocardium. Cardiovasc Res 26:556-557, 1992.

71. Miyamoto O, Auer RN. Hypoxia, hyperoxia, ischemia, and brain necrosis. Neurology 54:362-371, 2000.

72. Purshottam T, Kaveeshwar U, Brahmachari HD. Hypoxia tolerance in rats in relation to tissue glycogen levels. Aviat Space Environ Med 49:1062-1064, 1978.

73. Riepe MW, Esclaire F, Kasischke K, Schreiber S, Nakase H, Kempski $\mathrm{O}$ et al. Increased hypoxic tolerance by chemical inhibition of oxidative phosphorylation: "chemical preconditioning". J Cereb Blood Flow Metab 17:257-264, 1997.

74. Ruscher K, Isaev N, Trendelenburg G, Weih M, Iurato L, Meisel A, Dirnagl U. Induction of hypoxia inducible factor 1 by oxygen glucose deprivation is attenuated by hypoxic preconditioning in rat cultured neurons. Neurosci Lett 254:117-120, 1998.

75. Shizukuda Y, Mallet RT, Lee SC, Downey HF. Hypoxic preconditioning of ischaemic canine myocardium. Cardiovasc Res 26: 534-542, 1992.

76. Sutter $\mathrm{CH}$, Laughner E, Semenza GL. Hypoxia-inducible factor $1 \alpha$ protein expression is controlled by oxygen-regulated ubiquiti- nation that is disrupted by deletions and missense mutations. Proc Natl Acad Sci USA 97:4748-4753, 2000.

77. Huang LE, Bunn HF. Hypoxia-inducible factor and its biomedical relevance. J Biol Chem 278:19575-19578, 2003.

78. Semenza GL. Regulation of mammalian $\mathrm{O} 2$ homeostasis by hypoxia-inducible factor 1. Annu Rev Cell Dev Biol 15:551-578, 1999.

79. Ruscher K, Freyer D, Karsch M, Isaev N, Megow D, Sawitzki B et al. Erythropoietin is a paracrine mediator of ischemic tolerance in the brain: evidence from an in vitro model. $J$ Neurosci 22: 10291-10301, 2002.

80. Englander EW, Greeley GH Jr, Wang G, Perez-Polo JR, Lee HM Hypoxia-induced mitochondrial and nuclear DNA damage in the rat brain. J Neurosci Res 58:262-269, 1999.

81. Englander EW, Hu Z, Sharma A, Lee HM, Wu ZH, Greeley GH. Rat MYH, a glycosylase for repair of oxidatively damaged DNA, has brain-specific isoforms that localize to neuronal mitochondria. J Neurochem 83:1471-1480, 2002.

82. Lee HM, Wang C, Hu Z, Greeley GH, Makalowski W, Hellmich HL, Englander EW. Hypoxia induces mitochondrial DNA damage and stimulates expression of a DNA repair enzyme, the Escherichia coli MutY DNA glycosylase homolog (MYH), in vivo, in the rat brain. $J$ Neurochem 80:928-937, 2002.

83. Wang G, Hazra TK, Mitra S, Lee HM, Englander EW. Mitochondrial DNA damage and a hypoxic response are induced by $\mathrm{CoCl}(2)$ in rat neuronal PC12 cells. Nucleic Acids Res 28:21352140, 2000

84. Bergeron M, Ferriero DM, Vreman HJ, Stevenson DK, Sharp FR. Hypoxia-ischemia, but not hypoxia alone, induces the expression of heme oxygenase-1 (HSP32) in newborn rat brain. J Cereb Blood Flow Metab 17:647-658, 1997.

85. Mole DR, Maxwell PH, Pugh CW, Ratcliffe PJ. Regulation of HIF by the von Hippel-Lindau tumour suppressor: implications for cellular oxygen sensing. IUBMB Life 52:43-47, 2001.

86. Ratcliffe PJ. New insights into an enigmatic tumour suppressor Nat Cell Biol 5:7-8, 2003.

87. Maxwell PH, Ratcliffe PJ. Oxygen sensors and angiogenesis. Semin Cell Dev Biol 13:29-37, 2002.

88. Semenza GL, Nejfelt MK, Chi SM, Antonarakis SE. Hypoxiainducible nuclear factors bind to an enhancer element located 3 to the human erythropoietin gene. Proc Natl Acad Sci USA 88: 5680-5684, 1991.

89. Semenza GL, Roth PH, Fang HM, Wang GL. Transcriptional regulation of genes encoding glycolytic enzymes by hypoxiainducible factor 1. $J$ Biol Chem 269:23757-23763, 1994.

90. Clifford SC, Astuti D, Hooper L, Maxwell PH, Ratcliffe PJ, Maher ER. The pVHL-associated SCF ubiquitin ligase complex: molecular genetic analysis of elongin $\mathrm{B}$ and $\mathrm{C}, \mathrm{Rbx} 1$ and HIF-1 $\alpha$ in renal cell carcinoma. Oncogene 20:5067-5074, 2001.

91. Cockman ME, Masson N, Mole DR, Jaakkola P, Chang GW, Clifford SC et al. Hypoxia inducible factor- $\alpha$ binding and ubiquitylation by the von Hippel-Lindau tumor suppressor protein. $J$ Biol Chem 275:25733-25741, 2000.

92. Hon WC, Wilson MI, Harlos K, Claridge TD, Schofield CJ, Pugh $\mathrm{CW}$ et al. Structural basis for the recognition of hydroxyproline in HIF- $1 \alpha$ by pVHL. Nature 417:975-978, 2002.

93. Huang LE, Gu J, Schau M, Bunn HF. Regulation of hypoxiainducible factor $1 \alpha$ is mediated by an $\mathrm{O} 2$-dependent degradation domain via the ubiquitin-proteasome pathway. Proc Natl Acad Sci USA 95:7987-7992, 1998.

94. Iliopoulos O, Levy AP, Jiang C, Kaelin WG Jr, Goldberg MA. Negative regulation of hypoxia-inducible genes by the von Hippel-Lindau protein. Proc Natl Acad Sci USA 93:10595-10599, 1996.

95. Ivan M, Kaelin WG Jr. The von Hippel-Lindau tumor suppressor protein. Curr Opin Genet Dev 11:27-34, 2001.

96. Jakkkola P, Mole DR, Tian YM, Wilson MI, Gielbert J, Gaskell SJ et al. Targeting of HIF- $\alpha$ to the von Hippel-Lindau ubiquitylation complex by O2-regulated prolyl hydroxylation. Science 292:468-472, 2001.

97. Kamura T, Sato S, Haque D, Liu L, Kaelin WG Jr, Conaway RC, Conaway JW. The Elongin BC complex interacts with the conserved SOCS-box motif present in members of the SOCS, ras, 
WD-40 repeat, and ankyrin repeat families. Genes Dev 12:38723881, 1998.

98. Maher ER, Kaelin WG Jr. von Hippel-Lindau disease. Med (Baltimore) 76:381-391, 1997.

99. Maxwell PH, Wiesener MS, Chang GW, Clifford SC, Vaux EC, Cockman ME et al. The tumour suppressor protein VHL targets hypoxia-inducible factors for oxygen-dependent proteolysis. $\mathrm{Na}$ ture 399:271-275, 1999.

100. Ohh M, Park CW, Ivan M, Hoffman MA, Kim TY, Huang LE, Pavletich N, Chau V, Kaelin WG. Ubiquitination of hypoxiainducible factor requires direct binding to the beta-domain of the von Hippel-Lindau protein. Nat Cell Biol 2:423-427, 2000.

101. Ohh M, Takagi Y, Aso T, Stebbins CE, Pavletich NP, Zbar B et al. Synthetic peptides define critical contacts between elongin C, elongin $\mathrm{B}$, and the von Hippel-Lindau protein. $J$ Clin Invest 104:1583-1591, 1999.

102. Arany Z, Huang LE, Eckner R, Bhattacharya S, Jiang C, Goldberg MA, Bunn HF, Livingston DM. An essential role for $\mathrm{p} 300 /$ CBP in the cellular response to hypoxia. Proc Natl Acad Sci USA 93:12969-12973, 1996.

103. Kung AL, Wang S, Klco JM, Kaelin WG, Livingston DM. Suppression of tumor growth through disruption of hypoxia-inducible transcription. Nat Med 6:1335-1340, 2000.

104. O'Rourke JF, Dachs GU, Gleadle JM, Maxwell PH, Pugh CW, Stratford IJ et al. Hypoxia response elements. Oncol Res 9:327332, 1997.

105. Semenza GL, Jiang BH, Leung SW, Passantino R, Concordet JP, Maire P, Giallongo A. Hypoxia response elements in the aldolase A, enolase 1, and lactate dehydrogenase A gene promoters contain essential binding sites for hypoxia-inducible factor 1. J Biol Chem 271:32529-32537, 1996.

106. Vaux EC, Wood SM, Cockman ME, Nicholls LG, Yeates KM, Pugh CW et al. Selection of mutant $\mathrm{CHO}$ cells with constitutive activation of the HIF system and inactivation of the von HippelLindau tumor suppressor. $J$ Biol Chem 276:44323-44330, 2001.

107. Jones NM, Bergeron M. Hypoxic preconditioning induces changes in HIF-1 target genes in neonatal rat brain. J Cereb Blood Flow Metab 21:1105-1114, 2001.

108. Elkins JM, Hewitson KS, McNeill LA, Seibel JF, Schlemminger I, Pugh CW et al. Structure of factor-inhibiting hypoxia-inducible factor (HIF) reveals mechanism of oxidative modification of HIF-

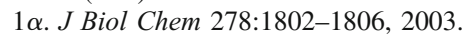

109. Epstein AC, Gleadle JM, McNeill LA, Hewitson KS, O'Rourke J, Mole DR et al. C. elegans EGL-9 and mammalian homologs define a family of dioxygenases that regulate HIF by prolyl hydroxylation. Cell 107:43-54, 2001.

110. Freedman SJ, Sun ZY, Poy F, Kung AL, Livingston DM, Wagner G, Eck MJ. Structural basis for recruitment of CBP/p300 by hypoxia-inducible factor-1 alpha. Proc Natl Acad Sci USA 99: 5367-5372, 2002.

111. Hewitson KS, McNeill LA, Riordan MV, Tian YM, Bullock AN, Welford RW et al. Hypoxia-inducible factor (HIF) asparagine hydroxylase is identical to factor inhibiting HIF (FIH) and is related to the cupin structural family. J Biol Chem 277:2635126355, 2002.

112. Ivan M, Haberberger T, Gervasi DC, Michelson KS, Gunzler V, Kondo $\mathrm{K}$ et al. Biochemical purification and pharmacological inhibition of a mammalian prolyl hydroxylase acting on hypoxiainducible factor. Proc Natl Acad Sci USA 99:13459-13464, 2002.

113. Masson N, Willam C, Maxwell PH, Pugh CW, Ratcliffe PJ. Independent function of two destruction domains in hypoxia-inducible factor- $\alpha$ chains activated by prolyl hydroxylation. Embo $J$ 20:5197-5206, 2001.

114. Min JH, Yang H, Ivan M, Gertler F, Kaelin WG Jr, Pavletich NP. Structure of an HIF- $1 \alpha$-pVHL complex: hydroxyproline recognition in signaling. Science 296:1886-1889, 2002.

115. Zhu H, Bunn HF. Signal transduction. How do cells sense oxygen? Science 292:449-451, 2001.

116. Semenza GL. Angiogenesis in ischemic and neoplastic disorders. Annu Rev Med 54:17-28, 2003.

117. Semenza GL. Oxygen-regulated transcription factors and their role in pulmonary disease. Respir Res 1:159-162, 2000.

118. Chavez JC, LaManna JC. Activation of hypoxia-inducible fac- tor- 1 in the rat cerebral cortex after transient global ischemia: potential role of insulin-like growth factor-1. J Neurosci 22: 8922-8931, 2002.

119. Zundel W, Schindler C, Haas-Kogan D, Koong A, Kaper F, Chen E et al. Loss of PTEN facilitates HIF-1-mediated gene expression. Genes Dev 14:391-396, 2000.

120. Oikawa M, Abe M, Kurosawa H, Hida W, Shirato K, Sato Y. Hypoxia induces transcription factor ETS-1 via the activity of hypoxia-inducible factor-1. Biochem Biophys Res Commun 289: 39-43, 2001.

121. Sanchez-Elsner T, Botella LM, Velasco B, Corbi A, Attisano L, Bernabeu C. Synergistic cooperation between hypoxia and transforming growth factor- $\beta$ pathways on human vascular endothelial growth factor gene expression. J Biol Chem 276:38527-38535, 2001.

122. Yin JH, Yang DI, Ku G, Hsu CY. iNOS expression inhibits hypoxia-inducible factor-1 activity. Biochem Biophys Res Commun 279:30-34, 2000.

123. Okada M, Fujita T, Sakaguchi T, Olson KE, Collins T, Stern DM, Yan SF, Pinsky DJ. Extinguishing Egr-1-dependent inflammatory and thrombotic cascades after lung transplantation. FASEB $J 15$ : 2757-2759, 2001.

124. Yan SF, Fujita T, Lu J, Okada K, Shan Zou Y, Mackman N et al. Egr-1, a master switch coordinating upregulation of divergent gene families underlying ischemic stress. Nat Med 6:1355-1361, 2000.

125. Yan SF, Lu J, Zou YS, Soh-Won J, Cohen DM, Buttrick PM et al. Hypoxia-associated induction of early growth response-1 gene expression. J Biol Chem 274:15030-15040, 1999.

126. Yan SF, Pinsky DJ, Stern DM. A pathway leading to hypoxiainduced vascular fibrin deposition. Semin Thromb Hemost 26: 479-483, 2000.

127. Yan SF, Zou YS, Gao Y, Zhai C, Mackman N, Lee SL et al. Tissue factor transcription driven by Egr-1 is a critical mechanism of murine pulmonary fibrin deposition in hypoxia. Proc Natl Acad Sci USA 95:8298-8303, 1998.

128. Millhorn DE, Beitner-Johnson D, Conforti L, Conrad PW, Kobayashi S, Yuan Y, Rust R. Gene regulation during hypoxia in excitable oxygen-sensing cells: depolarization-transcription coupling. Adv Exp Med Biol 475:131-142, 2000.

129. Schnell PO, Ignacak ML, Bauer AL, Striet JB, Paulding WR, Czyzyk-Krzeska MF. Regulation of tyrosine hydroxylase promoter activity by the von Hippel-Lindau tumor suppressor protein and hypoxia-inducible transcription factors. $J$ Neurochem 85: 483-491, 2003.

130. Bianchi L, Tacchini L, Cairo G. HIF-1-mediated activation of transferrin receptor gene transcription by iron chelation. Nucleic Acids Res 27:4223-4227, 1999.

131. Kietzmann T, Samoylenko A, Roth U, Jungermann K. Hypoxiainducible factor- 1 and hypoxia response elements mediate the induction of plasminogen activator inhibitor-1 gene expression by insulin in primary rat hepatocytes. Blood 101:907-914, 2003.

132. Lu S, Gu X, Hoestje S, Epner DE. Identification of an additional hypoxia responsive element in the glyceraldehyde-3-phosphate dehydrogenase gene promoter. Biochim Biophys Acta 1574:152156, 2002.

133. Minchenko A, Caro J. Regulation of endothelin-1 gene expression in human microvascular endothelial cells by hypoxia and cobalt: role of hypoxia responsive element. Mol Cell Biochem 208:53-62, 2000 .

134. Miyazaki K, Kawamoto T, Tanimoto K, Nishiyama M, Honda H, Kato Y. Identification of functional hypoxia response elements in the promoter region of the DEC1 and DEC2 genes. J Biol Chem 277:47014-47021, 2002.

135. Alafaci C, Salpietro F, Grasso G, Sfacteria A, Passalacqua M, Morabito A, Tripodo E, Calapai G, Buemi M, Tomasello F. Effect of recombinant human erythropoietin on cerebral ischemia following experimental subarachnoid hemorrhage. Eur J Pharmacol 406:219-225, 2000.

136. Bernaudin M, Marti HH, Roussel S, Divoux D, Nouvelot A, MacKenzie ET, Petit E. A potential role for erythropoietin in focal permanent cerebral ischemia in mice. $J$ Cereb Blood Flow Metab 19:643-651, 1999. 
137. Brines ML, Ghezzi P, Keenan S, Agnello D, de Lanerolle NC, Cerami $\mathrm{C}$ et al. Erythropoietin crosses the blood-brain barrier to protect against experimental brain injury. Proc Natl Acad Sci USA 97:10526-10531, 2000.

138. Buemi M, Cavallaro E, Floccari F, Sturiale A, Aloisi C, Trimarchi M, et al. Erythropoietin and the brain: from neurodevelopment to neuroprotection. Clin Sci (Lond) 103:275-282, 2002.

139. Calvillo L, Latini R, Kajstura J, Leri A, Anversa P, Ghezzi P et al. Recombinant human erythropoietin protects the myocardium from ischemia-reperfusion injury and promotes beneficial remodeling. Proc Natl Acad Sci USA 100:4802-4806, 2003.

140. Carmeliet P, Dor Y, Herbert JM, Fukumura D, Brusselmans K, Dewerchin M et al. Role of HIF-1 $\alpha$ in hypoxia-mediated apoptosis, cell proliferation and tumour angiogenesis. Nature 394:485490, 1998

141. Catania MA, Marciano MC, Parisi A, Sturiale A, Buemi M, Grasso $\mathrm{G}$ et al. Erythropoietin prevents cognition impairment induced by transient brain ischemia in gerbils. Eur J Pharmacol 437:147-150, 2002.

142. Celik M, Gokmen N, Erbayraktar S, Akhisaroglu M, Konakc S, Ulukus $\mathrm{C}$ et al. Erythropoietin prevents motor neuron apoptosis and neurologic disability in experimental spinal cord ischemic injury. Proc Natl Acad Sci USA 99:2258-2263, 2002.

143. Ehrenreich H, Hasselblatt M, Dembowski C, Cepek L, Lewczuk $\mathrm{P}$, Stiefel $\mathrm{M}$ et al. Erythropoietin therapy for acute stroke is both safe and beneficial. Mol Med 8:495-505, 2002.

144. Grasso G. Neuroprotective effect of recombinant human erythropoietin in experimental subarachnoid hemorrhage. $J$ Neurosurg Sci 45:7-14, 2001.

145. Kumral A, Ozer E, Yilmaz O, Akhisaroglu M, Gokmen N, Duman $\mathrm{N}$ et al. Neuroprotective effect of erythropoietin on hypoxicischemic brain injury in neonatal rats. Biol Neonate 83:224-228, 2003.

146. Sadamoto Y, Igase K, Sakanaka M, Sato K, Otsuka H, Sakaki S et al. Erythropoietin prevents place navigation disability and cortical infarction in rats with permanent occlusion of the middle cerebral artery. Biochem Biophys Res Commun 253:26-32, 1998.

147. Sakanaka M, Wen TC, Matsuda S, Masuda S, Morishita E, Nagao M, Sasaki R. In vivo evidence that erythropoietin protects neurons from ischemic damage. Proc Natl Acad Sci USA 95:46354640, 1998.

148. Solaroglu I, Solaroglu A, Kaptanoglu E, Dede S, Haberal A, Beskonakli E, Kilinc K. Erythropoietin prevents ischemia-reperfusion from inducing oxidative damage in fetal rat brain. Childs Nerv Syst 19:19-22, 2003.

149. Fink SL, Ho DY, McLaughlin J, Sapolsky RM. An adenoviral vector expressing the glucose transporter protects cultured striatal neurons from 3-nitropropionic acid. Brain Res 859:21-25, 2000.

150. Gupta A, Ho DY, Brooke S, Franklin L, Roy M, McLaughlin J, Fink SL, Sapolsky RM. Neuroprotective effects of an adenoviral vector expressing the glucose transporter: a detailed description of the mediating cellular events. Brain Res 908:49-57, 2001.

151. Lawrence MS, Ho DY, Dash R, Sapolsky RM. Herpes simplex virus vectors overexpressing the glucose transporter gene protect against seizure-induced neuron loss. Proc Natl Acad Sci USA 92:7247-7251, 1995.

152. Forsythe JA, Jiang BH, Iyer NV, Agani F, Leung SW, Koos RD, Semenza GL. Activation of vascular endothelial growth factor gene transcription by hypoxia-inducible factor 1. Mol Cell Biol 16:4604-4613, 1996.

153. Oosthuyse B, Moons L, Storkebaum E, Beck H, Nuyens D, Brusselmans K et al. Deletion of the hypoxia-response element in the vascular endothelial growth factor promoter causes motor neuron degeneration. Nat Genet 28:131-138, 2001.

154. Zaman K, Ryu H, Hall D, O'Donovan K, Lin KI, Miller MP et al. Protection from oxidative stress-induced apoptosis in cortical neuronal cultures by iron chelators is associated with enhanced DNA binding of hypoxia-inducible factor-1 and ATF-1/CREB and increased expression of glycolytic enzymes, p21(waf1/cip1), and erythropoietin. J Neurosci 19:9821-9830, 1999.

155. Schipani E, Ryan HE, Didrickson S, Kobayashi T, Knight M, Johnson RS. Hypoxia in cartilage: HIF- $1 \alpha$ is essential for chondrocyte growth arrest and survival. Genes Dev 15:2865-2876, 2001.

156. Dong Z, Nishiyama J, Yi X, Venkatachalam MA, Denton M, Gu $\mathrm{S}$, Li S, Qiang M. Gene promoter of apoptosis inhibitory protein IAP2: identification of enhancer elements and activation by severe hypoxia. Biochem J 364:413-421, 2002.

157. Fan C, Li Q, Ross D, Engelhardt JF. Tyrosine phosphorylation of I $\kappa \mathrm{B} \alpha$ activates NF $\kappa \mathrm{B}$ through a redox-regulated and $\mathrm{c}-\mathrm{Src}-$ dependent mechanism following hypoxia/reoxygenation. $J$ Biol Chem 278:2072-2080, 2003.

158. Green CJ, Lichtlen P, Huynh NT, Yanovsky M, Laderoute KR, Schaffner W, Murphy BJ. Placenta growth factor gene expression is induced by hypoxia in fibroblasts: a central role for metal transcription factor-1. Cancer Res 61:2696-2703, 2001.

159. Jung Y, Isaacs JS, Lee S, Trepel J, Liu ZG, Neckers L. Hypoxiainducible factor induction by tumour necrosis factor in normoxic cells requires receptor-interacting protein-dependent nuclear factor $\kappa \mathrm{B}$ activation. Biochem J 370:1011-1017, 2003.

160. Jung YJ, Isaacs JS, Lee S, Trepel J, Neckers L. Microtubule disruption utilizes an NFKB-dependent pathway to stabilize HIF-1 $\alpha$ protein. $J$ Biol Chem 278:7445-7452, 2003.

161. Liu Y, Cox SR, Morita T, Kourembanas S. Hypoxia regulates vascular endothelial growth factor gene expression in endothelial cells. Identification of a 5' enhancer. Circ Res 77:638-643, 1995.

162. Houston P, Dickson MC, Ludbrook V, White B, Schwachtgen JL, $\mathrm{McVey} \mathrm{JH}$ et al. Fluid shear stress induction of the tissue factor promoter in vitro and in vivo is mediated by Egr-1. Arterioscler Thromb Vasc Biol 19:281-289, 1999.

163. Silverman ES, Le L, Baron RM, Hallock A, Hjoberg J, Shikanai $\mathrm{T}$ et al. Cloning and functional analysis of the mouse 5-lipoxygenase promoter. Am J Respir Cell Mol Biol 26:475-483, 2002.

164. Wilder PJ, Bernadt CT, Kim JH, Rizzino A. Stimulation of the murine type II transforming growth factor-beta receptor promoter by the transcription factor Egr-1. Mol Reprod Dev 63:282-290, 2002.

165. Cramer T, Yamanishi Y, Clausen BE, Forster I, Pawlinski R, Mackman $\mathrm{N}$ et al. HIF-1 $\alpha$ is essential for myeloid cell-mediated inflammation. Cell 112:645-657, 2003.

166. An WG, Kanekal M, Simon MC, Maltepe E, Blagosklonny MV, Neckers LM. Stabilization of wild-type p53 by hypoxia-inducible factor 1 $\alpha$. Nature 392:405-408, 1998.

167. Blagosklonny MV, An WG, Romanova LY, Trepel J, Fojo T, Neckers L. p53 inhibits hypoxia-inducible factor-stimulated transcription. J Biol Chem 273:11995-11998, 1998.

168. Brusselmans K, Bono F, Maxwell P, Dor Y, Dewerchin M, Collen D, et al. Hypoxia-inducible factor- $2 \alpha$ (HIF- $2 \alpha)$ is involved in the apoptotic response to hypoglycemia but not to hypoxia. J Biol Chem 276:39192-39196, 2001.

169. Halterman MW, Miller CC, Federoff HJ. Hypoxia-inducible factor- $1 \alpha$ mediates hypoxia-induced delayed neuronal death that involves p53. J Neurosci 19:6818-6824, 1999.

170. Flavin MP, Zhao G. Tissue plasminogen activator protects hippocampal neurons from oxygen-glucose deprivation injury. J Neurosci Res 63:388-394, 2001.

171. Klein GM, Li H, Sun P, Buchan AM. Tissue plasminogen activator does not increase neuronal damage in rat models of global and focal ischemia. Neurology 52:1381-1384, 1999.

172. Tsirka SE. Tissue plasminogen activator as a modulator of neuronal survival and function. Biochem Soc Trans 30:222-225, 2002.

173. Wang YF, Tsirka SE, Strickland S, Stieg PE, Soriano SG, Lipton $\mathrm{SA}$. Tissue plasminogen activator (tPA) increases neuronal damage after focal cerebral ischemia in wild-type and tPA-deficient mice. Nat Med 4:228-231, 1998. 